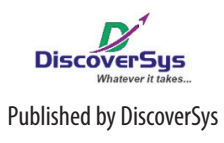

Published by DiscoverSys

\section{Early marriage as a risk factor for undernutrition among children aged under three years old in Gangga Subdistrict, North Lombok District}

\author{
Suhartiningsih, ${ }^{1 *}$ Ni Luh Putu Suariyani, ${ }^{2}$ Mangku Karmaya ${ }^{3}$
}

\title{
ABSTRACT
}

Background and purpose: The prevalence of severe and mild undernutrition among children aged under five years in North Lombok District is ranked second in West Nusa Tenggara Province after Bima City. The number of reported cases of early marriages in West Nusa Tenggara is higher than the national average. This study aims to examine the association between early marriages and undernutrition among children aged under three years in Gangga Subdistrict, North Lombok District.

Methods: A case-control study was conducted with a total of 49 cases (severe undernourished children) and 98 controls (normalweight children). A systematic random sampling was used to select all cases and controls from the health post register based on the weight/age indicator in Gangga Public Health Centre. Variables of sex and residency were matched between cases and controls. Data were collected from October to November 2016 through interviews with the mother at their house. Logistic regression using a software STATA SE 12.1 was employed to identify the association between early marriages and nutritional status of the children.

Results: Cases and controls were comparable based on children's gender, mother's age, area of residency, employment status of mother, and family income. There were significant differences on children's age and mother's education. Multivariate analysis showed an association between the nutritional status and early marriages with adjusted odds ratio $(A O R)=5.21(95 \% \mathrm{Cl}: 1.36-19.95)$, the frequency of sickness over the last three months $(A O R=1.93 ; 95 \% \mathrm{Cl}: 1.26-2.97)$ and low birth weight (AOR=14.12; 95\%Cl: 3.37-59.05).

Conclusions: Early marriages, frequency of sickness over the last three months, and low birth weight are associated with undernutrition among children aged under three years. Preventative measures to prevent early marriages, child infections and low birth weight need to be enhanced.

Keywords: Early marriage, frequency of sickness, low birth weight, undernutrition, West Nusa Tenggara

Cite This Article: Suhartiningsih, Suariyani, N.L.P., Karmaya, M. 2018. Early marriage as a risk factor for undernutrition among children aged under three years old in Gangga Subdistrict, North Lombok District. Public Health and Preventive Medicine Archive 6(1): 26-30. D01:10.15562/phpma.v6i1.5

'STIKES Mataram,

${ }^{2}$ Department of Public Health and Preventive Medicine, Faculty of Medicine, Udayana University, ${ }^{3}$ Department of Anatomy, Faculty of Medicine, Udayana University

*Correspondence to: Suhartiningsih, STIKES Mataram ningsihsuharti07@yahoo.com

\section{INTRODUCTION}

The UNICEF/WHO/World Bank group in 2016 reported the prevalence of wasting in children aged under five years was 51.7 million - with the highest prevalence in the Asia region (35.9 million). ${ }^{1}$ The Indonesia Basic Health Research (Riskesdas) in 2013 showed the prevalence of undernutrition in West Nusa Tenggara was $25.7 \%$ (weight/age), $45.3 \%$ (height/age), and $11.9 \%$ (weight/height). ${ }^{2}$ The prevalence of undernutrition in children aged under five years in North Lombok District is $32.0 \%$ (weight/age) and 65.8\% (height/age). ${ }^{3}$ This figure is the second highest in West Nusa Tenggara after Bima City. Early marriages in West Nusa Tenggara is high. It was reported that early marriages among teenage girls aged $15-19$ years in West Nusa Tenggara was $16.3 \%$. This figure is the fourth highest in Indonesia and significantly higher than the national average of $11.5 \% .{ }^{4}$

Studies have explored risk factors for undernutrition in children aged under five years in
Indonesia. However, the findings remain inconsistent, for example, studies in Mungkur Island and Mataram City. ${ }^{5,6,7}$ This present study aims to examine the association between early marriages and undernutrition in children aged under three years in Gangga Subdistrict, North Lombok District, West Nusa Tenggara.

\section{METHODS}

A case-control study was employed to examine the association between early marriages and undernutrition in children aged under three years in Gangga Subdistrict. A total of 49 cases (malnourished children) and 98 controls (normal-weight children) were selected using systematic random sampling from the health post register based on weight/age indicator. Sex and the area of residence between cases and controls were matched. Data 
Table 1 Characteristics of cases and controls

\begin{tabular}{|c|c|c|c|}
\hline Characteristics & $\begin{array}{l}\text { Cases } \\
\text { n (\%) }\end{array}$ & $\begin{array}{c}\text { Control } \\
\text { n (\%) }\end{array}$ & p value \\
\hline \multicolumn{4}{|l|}{ Sex (children) } \\
\hline Male & $27(55.10)$ & $56(57.14)$ & 0.233 \\
\hline Female & $22(44.90)$ & $42(42.86)$ & \\
\hline Children's age (months), mean \pm SD & $27.8 \pm 7.6$ & $22.24 \pm 7.2$ & 0.000 \\
\hline (Range) & $(12-36)$ & $(12-36)$ & \\
\hline Mother's age (years), mean $\pm S D$ & $27.7 \pm 6.12$ & $29.01 \pm 5.8$ & 0.216 \\
\hline (Range) & $(17-40)$ & $(18-47)$ & \\
\hline \multicolumn{4}{|l|}{ Area of residence } \\
\hline Bentek & $9(18.37)$ & $19(19.39)$ & 0.627 \\
\hline Gegelang & $10(20.41)$ & $28(28.57)$ & \\
\hline Gondang & $11(22.45)$ & $23(23.47)$ & \\
\hline Rempek & $13(26.53)$ & $16(16.33)$ & \\
\hline Sambik Bangkol & $6(12.24)$ & $12(12.24)$ & \\
\hline \multicolumn{4}{|l|}{ Mother's education } \\
\hline High (senior high and university) & $10(20.41)$ & $41(41.84)$ & 0.010 \\
\hline Low (junior high, primary, never schooling) & $39(79.59)$ & $57(58.16)$ & \\
\hline \multicolumn{4}{|l|}{ Mother's employment } \\
\hline Employed & $13(26.53)$ & $38(38.78)$ & 0.141 \\
\hline Housewives & $36(73.47)$ & $60(61.22)$ & \\
\hline Family income (IDR, million), median & 0.8 & 0.6 & 0.11 \\
\hline (Range) & $(0.1-4)$ & $(0.2-3.5)$ & \\
\hline
\end{tabular}

\section{Table 2 Association between under nutrition in children and several variables}

\begin{tabular}{|c|c|c|c|}
\hline Variables & $\begin{array}{l}\text { Cases } \\
\text { n (\%) }\end{array}$ & $\begin{array}{c}\text { Controls } \\
\text { n (\%) }\end{array}$ & p value \\
\hline \multicolumn{4}{|c|}{ Early marriage ( $\leq 15$ years) } \\
\hline Yes & $8(16.33)$ & $4(4.08)$ & 0.017 \\
\hline No & $41(83.67)$ & $94(95.92)$ & \\
\hline \multicolumn{4}{|c|}{ Exclusive breastfeeding } \\
\hline 0 month & $2(4.08)$ & $2(2.04)$ & 0.93 \\
\hline 1-2 months & $2(4.08)$ & $6(6.12)$ & \\
\hline 3-4 months & $2(4.08)$ & $5(5.10)$ & \\
\hline 5-6 months & $43(87.76)$ & $85(86.73)$ & \\
\hline \multicolumn{4}{|c|}{ Immunisation status } \\
\hline Complete & $43(87.76)$ & $89(90.82)$ & 0.56 \\
\hline Incomplete & $6(12.24)$ & $9(9.18)$ & \\
\hline \multicolumn{4}{|c|}{ Supplementary feeding initiation } \\
\hline 3-4 months & $0(0.00)$ & $3(3.06)$ & 0.30 \\
\hline 5-6 months & $43(87.76)$ & $86(87.76)$ & \\
\hline$\geq 7$ months & $6(12.24)$ & $9(9.18)$ & \\
\hline
\end{tabular}


Table 2 Association between under nutrition in children and several variables

\begin{tabular}{|c|c|c|c|}
\hline Variables & $\begin{array}{l}\text { Cases } \\
\text { n (\%) }\end{array}$ & $\begin{array}{c}\text { Controls } \\
\text { n (\%) }\end{array}$ & p value \\
\hline \multicolumn{4}{|l|}{ Source of water } \\
\hline Pipe water in the house & $17(34.69)$ & $26(26.53)$ & 0.57 \\
\hline Retail tap water & $0(0.00)$ & $2(2.04)$ & \\
\hline Boreholes & $28(57.14)$ & $63(64.29)$ & \\
\hline Well (dug, unprotected) & $0(0.00)$ & $1(1.02)$ & \\
\hline Water springs (protected) & $4(8.16)$ & $6(6.12)$ & \\
\hline \multicolumn{4}{|l|}{ The frequency of sickness (last 3 months) } \\
\hline Never & $7(14.29)$ & $22(22.45)$ & 0.15 \\
\hline$\leq 2$ times & $34(69.39)$ & $66(67.35)$ & \\
\hline$\geq 3$ times & $8(16.33)$ & $10(10.20)$ & \\
\hline Family income (IDR, million), median & 0.8 & 0.6 & 0.13 \\
\hline (Range) & $(0.1-4)$ & $(0.2-3.5)$ & \\
\hline \multicolumn{4}{|l|}{ Mother's employment } \\
\hline Employed & $13(26.53)$ & $38(38.78)$ & 0.14 \\
\hline Housewives & $36(73.47)$ & $60(61.22)$ & \\
\hline Parity, mean & 1.7 & 1.9 & 0.26 \\
\hline (Range) & $(1-5)$ & $(1-8)$ & \\
\hline \multicolumn{4}{|l|}{ Birth spacing } \\
\hline None (no sibling) & $25(51.02)$ & $47(47.96)$ & 0.92 \\
\hline$\geq 2$ years & $21(42.86)$ & $47(47.96)$ & \\
\hline$<2$ years & $3(6.12)$ & $4(4.08)$ & \\
\hline \multicolumn{4}{|l|}{ Mother's education } \\
\hline High (senior high and university) & $10(20.41)$ & $41(41.84)$ & 0.01 \\
\hline Low (junior high, primary, never schooling) & $39(79.59)$ & $57(58.16)$ & \\
\hline \multicolumn{4}{|l|}{ Birth weight } \\
\hline Low birth weight ( $\leq 2500$ grams) & $11(22.45)$ & $3(3.06)$ & 0.001 \\
\hline Normal birth weight (>2500 grams) & $38(77.55)$ & $95(96.94)$ & \\
\hline Total & $49(100.00)$ & $98(100.00)$ & \\
\hline
\end{tabular}

Table 3 Risk factors of undernutrition in children aged under three years

\begin{tabular}{lccc}
\hline Variables & Adjusted OR & $\mathbf{9 5 \%} \mathbf{C l}$ & p value \\
\hline Early marriage ( $\leq 15$ years) & 5.21 & $1.36-19.95$ & 0.016 \\
Frequency of sickness $\geq 3$ times (last 3 months) & 1.93 & $1.26-2.97$ & 0.002 \\
Low birth weight $(\leq 2500$ grams) & 14.12 & $3.37-59.05$ & 0.000 \\
\hline
\end{tabular}

were collected from October to November 2016 through interviews with the mother at their house. Written informed consent was obtained from the mother before the interview. STATA SE 12.1 was used to analyse the data of this study. Logistic regression was applied to identify the association between early marriages and undernutrition in children aged under three years.

Ethics approval was obtained from the Human Research Ethics Committee Faculty of Medicine
Mataram University, West Nusa Tenggara on October, $14^{\text {th }} 2016$.

\section{RESULTS}

Table 1 shows the characteristics of cases on controls which included sex, age of children, age of mother, area of residence, mother's education, mother's employment, and family income. It is found that cases and controls are comparable in 
several variables: sex, age of mother, area of residence, mother's employment, and family income $(p>0.05)$, but not comparable for the age of the child $(\mathrm{p}<0.01)$ and mother's education $(\mathrm{p}=0.010)$.

Table 2 shows the association between the nutritional status of children aged under three years and variables of early marriages $(p=0.017)$, exclusive breastfeeding $(\mathrm{p}=0.93)$, immunisation status ( $\mathrm{p}=0.56$ ), initiation of supplementary feeding $(p=0.30)$, source of water $(p=0.57)$, frequency of sickness over the last three months $(\mathrm{p}=0.15)$, family income $(\mathrm{p}=0.13)$, employment $(\mathrm{p}=0.14)$, parity $(\mathrm{p}=0.26)$, birth spacing $(\mathrm{p}=0.92)$, education $(\mathrm{p}=0.01)$, and birth weight $(\mathrm{p}=0.001)$. All variables with $\mathrm{p}$-value $<0.25$ were included in the multivariate analysis.

Table 3 shows the results of multivariate analysis. It was found that there is a significant association between under-nutrition in children aged under three years with early marriages ( $\leq 15$ years) $(\mathrm{AOR}=5.21 ; 95 \% \mathrm{CI}: 1.36-19.95)$, the frequency of sickness over the last three months $(\mathrm{AOR}=1.83$; 95\%CI: 1.20-2.78) and low birth weight $(\mathrm{AOR}=11.82$; 95\%CI: 2.88-48.44).

\section{DISCUSSION}

This study found a significant association between the nutritional status in children aged under three years with early marriages, the frequency of sickness ( $\geq 3$ times) over the last three months, and low birth weight.

In the present study, the early marriage was defined using the cut-off point of 15 years. However, if the cut-off point of 18 years is used, no significant association was found in this study $(\mathrm{AOR}=1.23$; 95\%CI: 0.61-2.47). A case-control study in India showed an association between undernutrition and early marriages (marital age of 15-24 years) with $\mathrm{AOR}=1.24 \quad$ (95\%CI: 1.14-1.36). ${ }^{8}$ Another study in Indonesia that re-analysed the Indonesia Basic Health Research 2010 data found an association between early marriages (marital age of $10-18$ years) and growth and development of children. ${ }^{5}$ A study in Nepal also found similar finding. Children aged 6-56 months who were born from mother aged $<20$ years or $>35$ years are 3.21 more likely to experience undernutrition compared to those who were born from mother aged 20-35 years (95\%CI: 1.30-7.94). ${ }^{9}$

In our study, the frequency of sickness ( $\geq 3$ times) over the last three months and low birth weight were found to be risk factors for undernutrition in children aged under three years. A case-control study in East Nusa Tenggara found that the frequency of sickness ( $\geq 4$ times) over the last six months is a risk factor for undernutrition in children with AOR=35.4 (95\%CI: 4.8-256.8). ${ }^{10}$ Similarly, a cross-sectional study in Manado City found an association between the frequency of sickness ( $>6$ times) over the last year and stunting $(\mathrm{p}=0.023) .{ }^{11}$ However, a case-control study in Salatiga City found no significant association between the frequency of sickness and underweight in children aged $2-5$ years $(\mathrm{p}=0.752){ }^{12}$

In our study, low birth weight is found to be a risk factor for undernutrition in children aged under three years. This finding is consistent with another case-control study in Mataram City. It found an association between low birth weight and stunting with $\mathrm{OR}=20.47$ (95\%CI: 1.16-354.25). ${ }^{7}$ A cross-sectional study in Vietnam also found an association between low birth weight and undernutrition in children aged under five years based on weight/age (OR=7.7; 95\%CI: 3.771-16.24), height/age (OR=5.6; 95\%CI: 2.84-11.33), and weight/ height (OR=5.2; 95\%CI: 2.38-11.0). ${ }^{13}$

The main limitation of this study is that the nutritional status was assessed based on weight/age which reflects only the acute malnutrition. Early marriages, frequency of sickness, and low birth weight are more likely to relate with the chronic undernutrition among children aged under three years. In addition, we only cover the limited area in Gangga Subdistrict, North Lombok District, leading to the limited generalizability of our findings to the wider population.

\section{CONCLUSION}

Early marriages, the frequency of sickness over the last three months, and low birth weight are significantly associated with undernutrition among children aged under three years. Preventative measures to prevent early marriages, child infections and low birth weight need to be enhanced.

\section{ACKNOWLEDGEMENT}

We would like to thank the head of Gangga Public Health Centre, North Lombok District and all respondents who participated in our study.

\section{REFERENCES}

1. UNICEF, WHO, World Bank Group. Levels and trends in child malnutrition. 2017. Available at: https://data. unicef.org/wp-content/uploads/ 2017/05/JME-2017brochure-1.pdf

2. Ministry of Health of Indonesia. The 2013 Indonesia Basic Health Research (Riskesdas). Jakarta; 2013. 
3. Ministry of Health of Indonesia. The 2013 Indonesia Basic Health Research (Riskesdas): West Nusa Tenggara Province. West Nusa Tenggara; 2013.

4. National Statistic Bureau and UNICEF. Kemajuan yang tertunda: analisis data perkawinan usia anak di Indonesia [Impending progress: analysis on the marital age in Indonesia]. 2016.

5. Afifah T. Pernikahan dini dan dampak status gizi pada anak (analisis data Riskesdas 2010) [Early marriages and nutritional status in children (an analysis of The Indonesia Basic Health Research 2010)]. Jurnal Gizi Indonesia. 2011;34(2):109-19.

6. Kaswari DM. Gambaran perilaku ibu yang menikah di usia dini dalam pemenuhan gizi balita di Desa Pulau Mungkur Kecamatan Gunung Toar Kabupaten Kuantan Singingi Provinsi Riau tahun 2012 (Skripsi) [Behaviours of young mothers in meeting minimal nutrient requirements of children aged under five years in Pulau Mungkur Village, Gunung Toar Subdistrict, Kuantan Singingi District, Riau Province, 2012 (Undergraduate thesis)]. Universitas Sumatera Utara. 2013.

7. Najahah I, Adhi KT, Pinatih GI. Faktor risiko balita stunting usia 12-36 bulan di Puskesmas Dasan Agung, Mataram, Provinsi Nusa Tenggara Barat [Risk factors of stunting in children aged 12-36 months in Dasan Agung Public Health Centre, Mataram City, West Nusa Tenggara]. Public Health and Preventive Medicine Archive. 2013;38.

8. Raj A, Saggurti N, Winter M, Labonte A, Decker MR, Balaiah D, et al. The effect of maternal child marriage on morbidity and mortality of children under 5 in India: cross-sectional study of a nationally representative sampel. BMJ. 2006;

9. Pravana NK, Piryani S, Chaurasiya SP, Kawan R, Thapa RK, Shrestha S. Determinants of severe acute malnutrition among children under 5 years of age in Nepal: a community-based case-control study. BMJ. 2017;1-8.
10. Ariesthi KD, Adhi KT, Wirawan DN. Faktor risiko gizi buruk dan gizi kurang pada balita di Kabupaten Sumba Barat Daya Nusa Tenggara Timur [Risk factors of malnutrition and underweight in children aged under five years in Sumba Barat Daya District, East Nusa Tenggara]. Public Health and Preventive Medicine Archive. 2015;3:27-33.

11. Tando NM. Durasi dan frekuensi sakit balita dengan terjadinya stunting pada anak SD di Kecamatan Malalayang Kota Manado [Frequency and duration of sickness in children aged under five years and its association with stunting in primary school aged children in Malalayang Subdistrict, Manado City]. Jurnal Gizi Indonesia. 2012;4(1):338-48.

12. Kusuma HS, Sunarto. Faktor determinan kejadian gizi kurang anak usia 2-5 tahun di desa pulutan Kecamatan Sidorejo Kota Salatiga [Determinants of underweight in children aged 2-5 years in Pulutan Village, Sidorejo Subdistrict, Salatiga City]. Available at: https://core.ac.uk/ download/pdf/11725157. pdf

13. Hien NN, Kam S. Nutritional status and the characteristics related to malnutrition in children under five years of age in Nghean, Vietnam. Jurnal Preventive Medicine of Public Health. 2008;41(4):232-40.

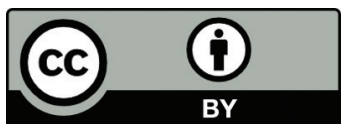

This work is licensed under a Creative Commons Attribution 